\title{
Polymer-Clay Nanocomposites and Composites: Structures, Characteristics, and their Applications in the Removal of Organic Compounds of Environmental Interest
}

Karina Abigail Hernández-Hernández, Javier Illescas*, María del Carmen Díaz-Nava, Claudia Rosario Muro-Urista, Sonia Martínez-Gallegos and Rosa Elena Ortega-Aguilar

Laboratorio de Investigación en Ingeniería Ambiental, División de Estudios de Posgrado, Instituto Tecnológico de Toluca, Av. Tecnológico S/N, Ex Rancho la Virgen, CP 52149, Metepec, Estado de México, México

\begin{abstract}
Nowadays, many organic contaminants, some of them byproducts from other types of reactions such as dyes or phenolic compounds, or even endocrine disruptors, pharmaceuticals, and personal care products, have been detected in wastewater. Most of them are not controlled and, possibly, can cause harmful effects in aquatic life at environmentally significant concentrations. It is noteworthy, that conventional wastewater treatment plants are not always effective for the removal of these classes of pollutants and so further water treatments are necessary. Therefore, many processes have been investigated for advanced treatment of these effluents as well as for organic pollutants degradation; among these, adsorption process has been used to remove them from wastewater. In addition, there has been a considerable development of new materials with interesting properties, both at large scale and at micro- or nanoscale. Some of these materials are more efficient than others, due to their dimensions in these latter scales, in different kind of applications; specifically, in the field of water treatment. This review is a brief survey of the main characteristics, structures, advantages and recent advances on polymer-clay composites (PCC's) and polymer-clay nanocomposites (PCN's), for environmental applications. In the first part are included some basic concepts: composite materials have components with contrasting yet complementary properties; e.g., organoclays which serve as reinforcement of polymeric matrices and give them a larger contact surface and greater mechanical strength. In particular, PCN's are materials that are used in different applications, for instance to model the morphology of partially crystalline polymers, to remove pollutants from water effluents, to employ them in adsorption processes from water streams, etc. Finally, in the second part, some of developments in the synthesis and applications of these novel materials are discussed; in particular, applications on the field of water pollutants removal through the adsorption process.
\end{abstract}

Keywords: Water pollution; Nanocomposites; Adsorption; Clays; Polymerization; Organic pollutants

\section{Introduction}

Water pollution by chief contaminants, such as organic compounds, is of major interest due to their high toxicity and persistence into the environment. For example, endocrine disruptor compounds, pharmaceuticals, personal care products, dyes and pigments and some byproducts of another reactions are persistent and bioactive contaminants, also known as emerging pollutants, continually introduced into the aquatic environment through different sources, which can result in toxic and adverse effects on aquatic organisms and consequently on humans. Some techniques exist to remove these and other micropollutants from water and industrial wastewater: chemical precipitation, conventional coagulation, reverse osmosis, ion exchange, electrodialysis, electrolysis and adsorption. From all of the cited before, adsorption is an economic technique that removes these organic pollutants from water. Nonetheless, it is important to consider the main drawbacks of the adsorption process, which are the regeneration costs, particularly if thermal process is implemented, the type of adsorbent for the treatment of a specific wastewater effluent and also the type of pollutants present in these wastewaters.

One possible strategy to resolve these disadvantages, for example, is the use of clays or clay minerals, polymers and/or activated carbon, which have played an important role in the removal of these organic compounds stated before. Particularly, clay minerals have received a great deal of attention due to their large specific surface area, cation exchange, low cost and toxicity. The adsorption of organic molecules to these minerals is affected by different considerations, such as the exchangeable cations, the distance between the clay mineral layers, and the existence of water molecules between the layers.
In the case of polymers, they are considered multipurpose materials, basically due to their advantageous properties such as easy manipulation, simple production and flexibility. Nevertheless, in some cases, polymers need to be altered in order to fulfill certain performance requirements. One methodology to modify polymer properties is to mix them with solid fillers, such as fibers, platelets, particles, other polymers, clays or clay minerals, resulting in polymeric composites or blends. A composite could be defined as a mixture of two or more materials possessing different physical and chemical properties with a very distinct interface. For composites, it is generally necessary to use a weight fraction of fillers in order to realize significant improvements in their properties. However, this presents both technical challenges and cost implications. Accomplishing property improvement in composites is one of the most important necessities to maximize the overall area of the interface between the matrix and the filler. In this sense, nanotechnology, which involves fillers in the nanometer scale, offers an attractive alternative. Under such conditions, the filler and polymer

*Corresponding author: Javier Illescas, Laboratorio de Investigación en Ingeniería Ambiental, División de Estudios de Posgrado, Instituto Tecnológico de Toluca, Av. Tecnológico S/N, Ex Rancho la Virgen, CP 52149, Metepec, Estado de México, México, Tel: +52-7222087224/2087200; E-mail: fillescasm@toluca.tecnm.mx

Received February 04, 2016; Accepted March 25, 2016; Published March 29 2016

Citation: Hernández-Hernández KA, Illescas J, Díaz-Nava MdC, Muro-Urista CR, Martínez-Gallegos S, et al. (2016) Polymer-Clay Nanocomposites and Composites: Structures, Characteristics, and their Applications in the Removal of Organic Compounds of Environmental Interest. Med chem (Los Angeles) 6: 201210. doi:10.4172/2161-0444.1000347

Copyright: (C) 2016 Hernández-Hernández KA, et al. This is an open-access article distributed under the terms of the Creative Commons Attribution License, which permits unrestricted use, distribution, and reproduction in any medium, provided the original author and source are credited. 
could be in intimate contact almost at the molecular level, possibly yielding substantial improvements in system properties. The possible property improvements could affect thermal, mechanical, electrical, flammability and barrier performance, with only small changes in density and optical properties.

This review covers the various PCN's that have been used as adsorbents for organic pollutants removal. Also, it discusses the synthesis of these materials used as an alternative for the adsorption processes.

\section{Polymer Composites and Nanocomposites}

Polymer composites (PC's) consist of different types of short or continuous fibers bound together by an organic polymer matrix. These are often divided into two categories: 1) reinforced plastics and 2) advanced composites. This difference is based on the level of the mechanical properties, for instance, strength and stiffness. Some advantages of these compounds are their lightweight coupled with high stiffness along the direction of the reinforcement. They are constituted of two phases: the continuous phase called matrix, and the dispersed phase that is mainly called as the reinforcing phase.

On the other side, nanotechnology refers to matter manipulation at atomic or molecular scale using nanoscale matter and structures, which can range from 1 to $100 \mathrm{~nm}$. Due to their size, materials present physical and chemical properties that make them unique, such as surface area, volume and the high interfacial reactivity ratio they have. The increase in nanocomposite synthesis has so far shown its versatility, particularly in the science and technology of polymers, fundamentally in applications such as improving barrier properties, flame resistance, optoelectronic properties, cosmetic applications, bactericides and specially water pollution removal [1-3].

Nanocomposites consist of matrices of different materials, which can be polymer, metal or ceramic, and to which is added the charge, e.g., multiwalled carbon nanotubes, activated carbon, reduced graphene oxide, natural clays, graphene-like materials etc., that gives new properties to the material, which helps in a specific application. Among these types, polymeric ones have proven to be the most versatile for their application in several research fields like engineering, building, optoelectronics, medicine, and environmental remediation, in particular removing water pollutants. Overall, nanocomposites have better adsorption capacity, stability and selectivity than other materials in nanometric scale.

\section{Constituents of polymer nanocomposites}

As it has been previously stated, PCs can be defined as polymers that have been filled with natural or synthetic compounds to improve their properties. In some other cases, the filler has been incorporated to reduce the cost by acting as a diluent for the polymer, Trindade et al. [4]. In this context, the polymer is called "matrix"; if the filler is in the nanometer range, the composite is called "nanocomposite". These nanocomposites consist mainly of three components, whose characteristics will be described below:

Matrix: The properties of the matrix determine the resistance of the polymeric nanocomposites in most degradation processes, which eventually cause structural failure. These processes include impact damage, delamination, water absorption, chemical attack and deformation at high temperatures. It is because of this, that the matrix is generally the weakest link in the structure of these materials. Thus, according to the resistance of the nanocomposite matrix to the degradative process that can cause a failure of the structure, it can be classified as follows:
Thermostable: Among the matrices in this category are polyester, vinylester, epoxy, bis-maleimide and polyamide resins. Thermostable polyesters are used in fiber-reinforced plastics, whereas epoxy resins have the biggest advanced composite market. The viscosity of these resins is low; however, thermostable resins suffer chemical reactions that intersect the polymer chains, so the matrix is connected in a threedimensional network. This process is known as curing. Thermostable polymers, due to this intersected three-dimensional structure, tend to have high dimensional stability, high temperature resistance and good resistance to solvents. Considerable progress has been recently made to improve the tenacity and maximum operating temperature of thermostable polymer nanocomposites.

Thermoplastic: Thermoplastic resins, sometimes called engineering plastics, include some polyesters, polyetherimides, polyamide-imides, polyphenylene sulfurs, polyether ether ketones and some liquidcrystalline polymers. They consist of molecules that melt in a viscous liquid at process temperature, usually between 533 and $644 \mathrm{~K}$, and once formed they cool until an amorphous, semi-crystalline or crystalline solid is formed. The degree of crystallinity has great effect in the matrix's final properties. Unlike the curing process, the process of synthesis of thermoplastics is reversible, since when it is reheated to process temperature, the resin can be synthesized in any other desired form. Although thermoplastics have lower temperature resistance and chemical stability, they are more resistant to cracking and impact damage. However, recent advances in thermoplastics synthesis, such as polyether ether ketones, which have a semi-crystalline structure, present excellent resistance to high temperature and solvents.

Moreover, depending on their application, polymer matrices used in nanocomposite synthesis are classified as: general use polymers, engineering plastics, conductive polymers and biodegradable polymers.

General use polymers: These polymers represent the majority of the total production of plastics in the world and are characterized by its use in low-cost applications and generally have low mechanical performance. That is why nanocomposite synthesis with this kind of polymer aids in improving its properties and potentiates its applications. Examples of these are poly(vinylchloride), polyethylene, polypropylene, etc. [5-7].

Engineering plastics: These are materials which can be used, as their name indicates, in engineering applications; to mention a few, structural and equipment parts, as substitute parts, especially metal, due to their better mechanical and chemical properties in relation to general use polymers. Examples of this type of matrix are polyamide and polysulfones [8-10].

Conductive polymers: This type of polymer, also known as synthetic metals, have electric, magnetic and optical properties which can be compared to those of semiconductors. They are also called conjugated polymers because they present conjugated $\mathrm{C}=\mathrm{C}$ links in their main chains, which allows for the creation of an electron flux under certain conditions. The conductivity of this kind of polymer depends on the polymer chain order at the moment of synthesizing the nanocomposite. Examples of this are polyaniline and poly(ethylene oxide) $[11,12]$.

Biodegradable polymers: This type of polymers, when subject to a certain microbial activity, present cut-off chains. To obtain an optimal biodegradability of the polymer, certain specific conditions are needed, such as $\mathrm{pH}$, humidity, or the presence of some metals. Biodegradable polymers can be obtained from natural sources like corn, cellulose; or sources derived from petroleum or a mixture of petroleum and biomass. An example of this is polyhydroxybutyrate [13].

Filler: Fillers in nanocomposites, also known as charge or 
reinforcements, are responsible for their high resistance and rigidity. It is precisely this constituent that is found at nanoscale. Some of the most important composites used are: exfoliated clays, carbon nanotubes, carbon nanofibers, exfoliated graphite (graphene), nanocrystalline metals and some nanoscale inorganic fillers or modified fibers. Of all these fillers, exfoliated clays produce important advantages in the mechanical properties for the modification of polymeric systems [14-16].

Clays: Clays study does not just involve the material, but also the interaction with their environment. This interaction results from the influence of the environment over the clay; for instance, the acid/base character ( $\mathrm{pH}$ and ionic strength) and the thermodynamic conditions (pressure and temperature) of the surrounding environment. Furthermore, the interaction between clay-like minerals and other composites in the environment can occur in different states of matter (solid, molten solid, liquid, gas and plasma). Therefore, its study is related to the classic disciplines of physics and chemistry of solid and liquid states, as well as developing disciplines in the science of the molten and plasma states.

The main characteristic of clays is that they are studied by many disciplines for basic and applied research. By studying the same sample through different techniques, very important and valuable information is obtained in a very interesting research area, mainly due to the fact that clays are abundant, easily obtainable and very cheap when compared to other materials.

In the particular case of PCN's, clays promote very important technical advantages such as improvements in: i) mechanical properties, ii) barrier properties, iii) thermal properties, iv) degradative properties, v) flame resistance, and vi) rheological properties. To mention but one example, clay can increase the glass transition temperature $\left(\mathrm{T}_{\mathrm{g}}\right)$ of a polymer, which positively affects the heat distortion temperature.

Interface: The interface in PCN's is the region in which loads are transmitted between the matrix and the filler. The degree of interaction between them is a variable that depends on the nanocomposite's design, and it can range from very strong chemical links to very weak friction forces. This can be controlled by using an appropriate covering in the reinforcement fibers. Generally speaking, a steady interfacial bond makes the polymer nanocomposite stiffer, but brittle. On the contrary, a weak bond decreases stiffness, but enhances toughness. If the interfacial bond is not at least as tough as the matrix, debonding can occur at the interface under certain loading conditions. To take full advantage of the fracture toughness of these nanocomposites, the most necessary coupling occurs between the strong and weak limits. The character of the interfacial bond is also critical to the long-term stability of the nanocomposite, playing a crucial role in environmental behavior, fatigue properties, and resistance conditions.

\section{Polymer-clay nanocomposite synthesis}

As it has been stated before, nanocomposites are made of a matrix and reinforcement. The support is a polymer formed by a carbon chain and different types of functional groups bonded to it, which can confer a hydrophobic character to the structure. On the other hand, clayfillers are usually hydrophilic, which at first sight would make it seem like there is a chemical incompatibility between them, so optimizing clay dispersion and inserting polymeric chains is a necessity in these materials in order to obtain a nanocomposite. A possibility for realizing this is through organic modification of clay which decreases its hydrophilicity, or by using a compatibilizing agent inside the polymer structure; i.e., performing a graft to increase its polarity.

In situ polymerization: In this type of PCN's synthesis, the monomer is used as a mean for the dispersion of the charge (clay) and some favorable conditions are set to realize the polymerization between its layers. As clay has greater surface energy, it performs an attraction to monomer units inside its galleries until balance is achieved and polymerization reactions occur between layers with lower polarity, shifting the balance and then having as an objective the diffusion of new polar species between layers, Figure 1 .

As an example, Baniasadi et al. [17] used this method to obtain exfoliated polypropylene-based nanocomposites using a bi-supported catalyst. Nonetheless, in situ polymerization is limited because a suitable monomer-silicate solvent system is not always available and compatible with current polymer-process techniques.

Dispersion in solution: In this method of synthesis, clay is exfoliated in single layers using a solvent in which the polymer or prepolymer is soluble. The clay's layers can be easily dispersed in the solvent through the increase of entropy due to the layers' disorganization, which exceeds the laminates' organizational entropy value. Afterwards, the polymer is embedded into the delaminated layers and when the solvent is evaporated or the mixture is precipitated, the layers merge with the polymer as filler, Figure 2 .

This technique is especially employed with water-soluble polymers. For example, polyvinyl alcohol (PVA) used by Strawhecker and Manias [18], poly(acrylic acid) employed by Billingham et al. [19], and poly(ethylene oxide) by Malwitz et al. [20]. That is due to the polarity of these polymers, which is believed to contribute an enthalpy gain helping intercalation. Therefore, the main requirement of this method is that the chosen polymer should be compatible with the chosen solvent. Remarkably, this method produces a high degree of intercalation only

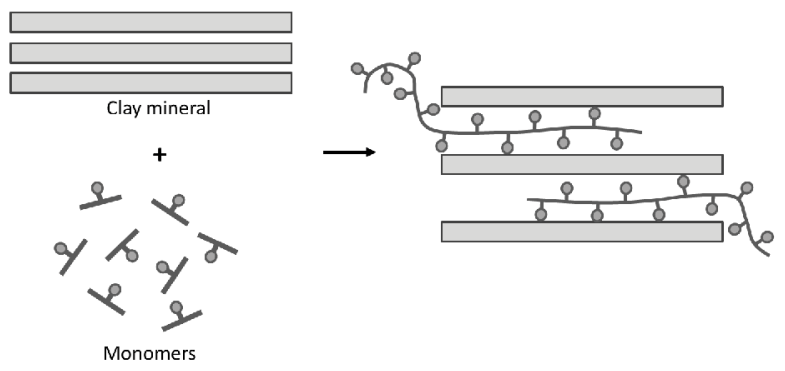

Figure 1: In-situ polymerization synthesis of PCN's.

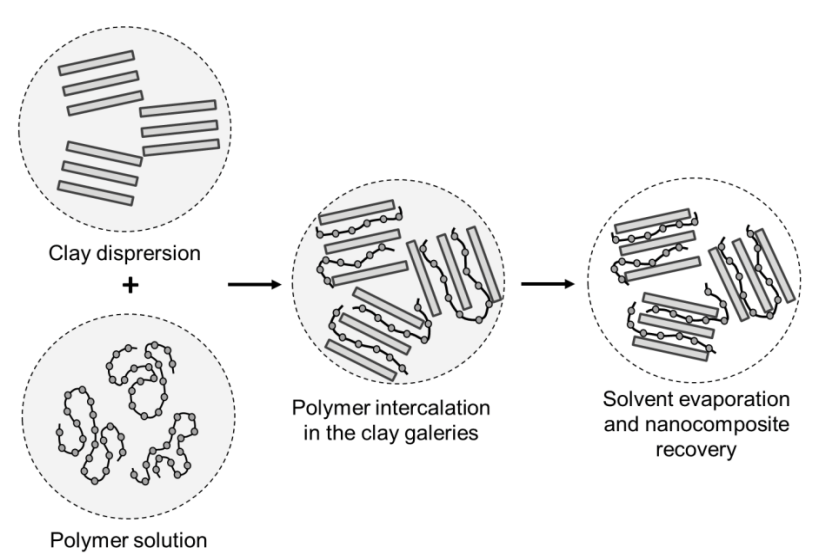

Figure 2: Synthesis of nanocomposites by dispersion in solution technique. 
for specific polymer/clay/solvent systems, suggesting that for a given polymer, one has to find the right clay, organic modifier and solvents.

Intercalation in molten state: In this technique, developed by Vaia et al. [21], the clay is mixed with a thermoplastic polymer matrix in its molten state, Figure 3. Under these conditions, the polymer is taken to the space between the layers forming a nanocomposite. The driving force in this process is the enthalpic contribution of the interactions between polymer and clay, which in this case fulfills the functions of the nanocharge.

Particularly, this method is very attractive, since is the most flexible and environmentally benign from all the existing methods of preparing PCN's. Nanocomposite synthesis comprises compounding and annealing of a mixture of polymer and clay above the melting point of the polymer. During compounding and blending, the polymer melt diffuses into the cavities of the clay. Hence, it allows the processing of PCN's to be articulated directly from the precursors without using any solvent but conventional compounding devices such as mixers and/or extruders.

Some used polymers are polycaprolactone, [22] thermoplastic polyurethane [23], and ethylene vinyl acetate [24]. Also, Wan et al. [25] investigated the effect of silicate modification and montmorillonite (MMT) content on the morphology development, relaxation behavior, and mechanical properties of the poly(vinyl chloride)/montmorillonite (PVC/MMT) nanocomposites. In a similar way, Cabedo et al. [26] prepared ethylene-vinyl alcohol (EVOH) nanocomposites, incorporating kaolinite, by this process.

Between some advantages of this method of synthesis is that this approach does not use any organic solvent, and it is compatible with current industrial polymer extrusion and blending processes. However, some disadvantages presented by intercalation in molten state are that forms microcomposites at higher clay loading as a consequence of clay agglomeration. Moreover, this technique uses thermoplastic polymers, which are normally hydrophobic, and this restricts the application of nanocomposites in water treatment.

\section{Environmental Applications of Polymer-Clay Nanocomposites}

Possibly, one of the most intensely studied applications of PCN's is the removal of inorganic contaminants from aqueous solutions. However, PCN's have also been intensively used for the removal of organic pollutants from water. For instance, dyes and pigments, pharmaceuticals and personal care products, surfactants, pesticides, herbicides, different industrial additives and several chemicals, claimed to be endocrine disrupter, are not metabolized and discharged into drains and wastewater treatment plants. For most organic

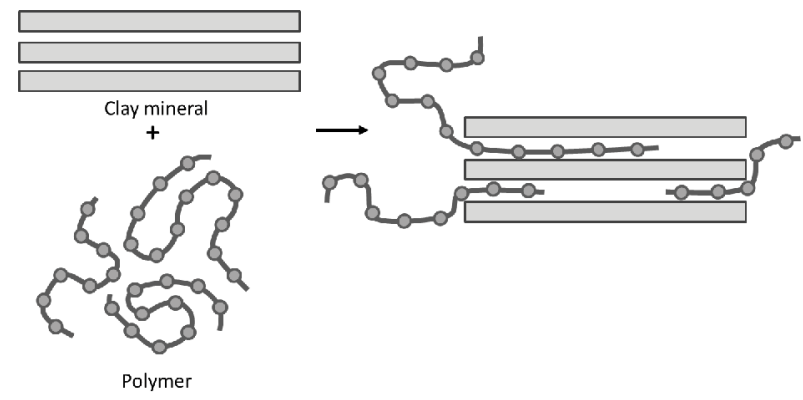

Figure 3: Nanocomposites synthesized by intercalation in molten state. contaminants, incidence, risk assessment and ecological-toxicological data are not available, and it is hard to predict their fate in the aquatic environment. The reason for this is a lack of analytical methods for their determination at trace concentrations. Analysis of organic contaminants is a real analytical challenge, not only because of the variety of chemical properties of these compounds, but also because of their low concentrations (usually at part per billion (ppb) or part per trillion (ppt) levels). In addition, these compounds have received little attention because they are not on regulatory lists as environmental pollutants. However, today analytical methodologies for different groups of organic contaminants are being developed, and a rising number of methods are reported in the literature. Recent studies have demonstrated the great amount of research made in the field of water treatment on three main types of pollutants: organic dyes and pigments, phenolic compounds, and emerging organic contaminants such as herbicides, pesticides, pharmaceuticals and endocrine disruptor compounds.

Mainly, we are citing three types of water pollution: 1) contamination due to the discharge of untreated or partially treated industrial dye wastewaters into the ecosystem. This problem has been reported by Akar and Uysal [27]. Furthermore, in several industry processes, such as textiles $[28,29]$, leather, rubber, paper [30], plastic and so on, the incorporation of dyes are one of the most polluting industrial processes because they produce enormous quantities of colored wastewaters. As it has been previously reported by Rafatullah et al. [31], in addition to their color, some of these dyes could degrade to highly toxic products: carcinogenic, mutagenic and allergenic for exposed organisms even at low concentrations (less than $1 \mathrm{ppm}$ ). They contaminate not only the environment, but also the entire food chain, leading to biomagnifications.

Phenolic compounds: These pollutants have been found as byproducts from diverse industrial processes, such as in the synthesis of dyes, aspirin, paper, etc. Even in low concentration, phenol causes toxicity and foul odor to the water. This is due to its reactivity with chlorine $(\mathrm{Cl})$ and nitrate $\left(\mathrm{NO}_{2}\right)$ in the soil to form chlorophenol and nitrophenol, respectively. Most countries specify a maximum allowable concentration of phenol in wastewater to be less than 1 ppm $[32,33]$. The exposure of phenol and its derivative compounds to human and animals causes liver and kidney damage, central nervous system impairment, diarrhea, and excretion of dark urine $[34,35]$. Therefore, it is necessary to develop methods that allow one to detect, quantify and remove phenol from wastewater [36].

Emerging contaminants: These pollutants have been detected in wastewater treatment plant effluents, in shallow waters, seawater, subterranean waters and in some drinking waters. Their concentration in the effluents varies depending on the country and the consumption; these substances are bioaccumulative, so they pose a great danger for the environment and humans [37-40]. Some examples of these kinds of contaminants are pesticides and herbicides, pharmaceutical products, such as antibiotics and microbial agents, personal hygiene products, like shampoo, detergents, and so on.

In addition, although activated carbon remains one of the most widely used adsorbent, its relatively high cost limits its use. However, adsorptive properties and availability are important criteria when choosing an adsorbent for contaminant removal, thereby encouraging research into materials that are not only efficient but also cheap. Many non-conventional low-cost adsorbents, including natural materials, biosorbents, and waste materials from agriculture and industry have been proposed by Namasivayam et al. [41-44]. As mentioned before, considering low cost, abundance and high sorption properties, clay 
minerals are interesting materials for use as adsorbents, since they can be easily obtained and regenerated, as it has been demonstrated by Gil et al. [45].

\section{Organic Compounds Removal from Water with Polymer-Clay Nanocomposites}

Nowadays, the conventional water treatment technology involves different processes such as coagulation, chlorination, flocculation, filtration, ozonation and sedimentation. Coagulation and flocculation processes are used to remove suspended particles, such as bacteria, clay, silts and organic matter from the contaminated water; however, it also leads to the removal of minerals from water, resulting in a decrease of its quality. Sedimentation and filtration processes could be used for the removal of floc and sludge; but, it is necessary to check the condition of the sedimentation bed, which increases the cost of water purification. Finally, chlorination and ozonation could remove microbes present in water, since both chlorine and ozone are well-known oxidizing agents that can react with organic matter to generate disinfectant byproducts such as bromate, chlorite, haloacetic acids and trihalomethanes. All of the mentioned disadvantages in the former processes have created the need for a new type of technology that can overcome the problems and allow easy access to pure water.

Nanotechnology has arisen as a possibility to the conventional water treatment technologies for effective removal of chemical and microbial contaminations due to their large surface-area-to-volume ratio, enhanced catalytic properties, high conductivity, antimicrobial properties and self-assembly on surfaces. Currently, nanotechnologyenabled water treatment technology principally focuses on two major areas to improve its quality:

a) Degradations of organic pollutants, and

b) Removal of pollutants by adsorption process.

Adsorption is a surface phenomenon in which adsorbate molecules (liquid or gas) are concentrated on the surface of a solid (adsorbent). Gupta and Suhas [46] defined this process as physisorption or chemisorption depending on how the adsorbate species get adsorbed onto the adsorbent surface. Kumar et al. $[47,48]$ explained that dyes molecules may be adsorbed on the surface of an adsorbent through several forces such as hydrogen bonding, electrostatic interaction, van der Waals forces, hydrophobic interaction etc. Usually, adsorbents possess porous structures, which increase the total exposed surface area and allow fluid to pass through faster.

Meanwhile, Kyzas et al. [49] described adsorption as a simple and economical method for dye-pollutants removal from water and wastewater. It has high treatment efficiency and adsorbents can be regenerated for multiple purposes. Initial pollutant concentration, temperature, solution $\mathrm{pH}$, adsorbent dosage and contact time are the main aspects that control the performance of most of the adsorption process.

In the case of organic compounds, adsorption has been extensively studied with different porous materials such as clay minerals. That is why the search for new types of materials, such as PCC's and PCN's, has been developed. Specifically they have been synthesized for the removal of highly pollutant organic substances, e.g., dyes; some byproducts of phenolic compounds and a new kind of pollutant known as "emerging pollutants", among which can be counted some pharmaceuticals, steroids, pesticides, endocrine disruptive compounds and so on.

\section{Dyes removal}

Wastewater discharges from dyeing or finishes of textile industries, as well as of some food, pharmaceutical or chemical industries contain various types of dyes, many of which are mutagenic or cancerogenous for humans [45]. They are important because they are used to give color to other materials and are absorbed when applied. Dyes discharge in bodies of water is an important environmental problem, since there is no norm to limit it in Mexico, and they could change when exposed to sunlight, to acids, excessive heat, etc. Dye dissemination into water bodies leads to colored water, which is a visible concern. These dispersed dye molecules block sunlight from reaching the bulk of affected water system, and therefore, reduce the dissolved oxygen (DO) level in water. Dyes may also increase the biochemical oxygen demand (BOD) of the contaminated water body.

Among the reported treatments for the removal of dyes are: separation membranes [50-54], coagulation-flocculation [48,51,52,55], biological degradation [56] or advanced oxidation [57,58], and among which stands out adsorption [45,59-68].

Dye-adsorption with nanocomposites and composites acquires relevance because of the potential it offers, as shown on Table 1 .

\section{Phenolic compounds removal}

Phenol and its byproducts are some of the most extensively studied organic pollutants due to their toxicity to living beings and the environment. Phenolic pollutants discharged from different kind of industries, such as pesticides, paints, polymer resins, paper, and petrochemistry have been found in their effluents $[69,70]$. There are two main treatment technologies for phenolic compounds: the first consists of chemical oxygenation processes with reagents such as hydrogen peroxide [71,72], and the second of adsorption and extraction processes [73-75]. Chemical adsorbents such as clays and clay minerals, and even polymers play an important role in the removal of these compounds [76-79]. Clay minerals, in particular, received a great deal of attention due to their large specific surface area and cation exchange capacity on the one hand, and low cost and toxicity on the other $[80,81]$. The adsorption of organic molecules to these minerals is affected by various parameters, such as the exchangeable cations, the distance between the clay mineral layers, and the existence of water molecules between the layers [80].

Also, adsorption onto a polymeric sorbent, (SP206, a polystyrene matrix crosslinked with divinyl benzene) by Moon et al. [82] showed that phenol, p-chlorophenol, and p-nitrophenol adsorption data had a maximum adsorption capacity of $0.0626,0.736$ and $0.815 \mathrm{mg} \cdot \mathrm{g}^{-1}$ respectively. They also reported that phenolic compounds on SP206 were desorbed very quickly with a $0.05 \mathrm{~N}$ sodium hydroxide solution within a few minutes.

Also, the adsorption of o-nitrophenol onto nano-iron oxide loaded with calcium alginate beads was studied by Soni et al. [83]. It was observed that the optimum $\mathrm{pH}$ for the adsorption was 2 . Similarly, the equilibrium time was 4 hours with percentage removal of $96 \%$. Besides, Chen et al. [84] studied the adsorption of phenol and 4-nitrophenol on $\mathrm{Mg} / \mathrm{Al}$ oxide derived from $\mathrm{Mg} / \mathrm{Al}$-layered double hydroxide $(\mathrm{Mg} /$ Al-LDH). They observed that it took 10-12 $\mathrm{h}$ for the adsorption of 4-nitrophenol to reach equilibrium, in comparison with that of phenol which was $24 \mathrm{~h}$. The kinetic process followed the Lagergren's firstorder model for 4-nitrophenol and the pseudo-second order model in the case of phenol. They also noted that the adsorption capacity for 4-nitrophenol could be as high as $367.8 \mathrm{mg} \cdot \mathrm{g}^{-1}$, while that of phenol was 
Citation: Hernández-Hernández KA, Illescas J, Díaz-Nava MdC, Muro-Urista CR, Martínez-Gallegos S, et al. (2016) Polymer-Clay Nanocomposites and Composites: Structures, Characteristics, and their Applications in the Removal of Organic Compounds of Environmental Interest. Med chem (Los Angeles) 6: 201-210. doi:10.4172/2161-0444.1000347

\begin{tabular}{|c|c|c|c|}
\hline PCN or PCC system & Dye & Enhancement action of PCN or PCC system & Authors \\
\hline $\begin{array}{l}\text { Poly(acrylamide)/Laponite Clay (PAAm/ Lap) } \\
\text { hydrogel nanocomposite }\end{array}$ & $\begin{array}{l}\text { Basic Blue } 12 \text { (BB12), Basic Blue } 9 \\
\text { (BB9) and Basic Violet } 1 \text { (BV1) }\end{array}$ & $\begin{array}{l}\text { Dye uptake speed and equilibrium amount } \\
\text { increases significantly with increasing of clay } \\
\text { content up to } 40 \%\end{array}$ & Li et al. [58] \\
\hline $\begin{array}{l}\text { Poly(acrylic acid)/Bentonite/FeCo particles (PAAc-B- } \\
\text { FeCo) hybrid hydrogel nanocomposite }\end{array}$ & Crystal Violet (CV) & $\begin{array}{l}\text { Exfoliated bentonite clay and Fe-Co particles } \\
\text { increased the strength and stability of hydrogel } \\
\text { and assisted the adsorption of CV }\end{array}$ & Shirsath et al. [90] \\
\hline $\begin{array}{l}\text { Poly(acrylamide-co-sodium acrylate-co- } \\
\text { Carrageenin)/Sodium-Montmorillonite P(AAm-Na- } \\
\text { AA-NaMMT) clay nanocomposite }\end{array}$ & Crystal Violet (CV) & $\begin{array}{l}\text { Enhancement in CV adsorption speed was } \\
\text { observed when the AAm amount in AAm/Na-AA } \\
\text { ratios increased up to } 50 \text { wt- } \% \text {. }\end{array}$ & Reza-Mahdavinia et al. [91] \\
\hline PAAm/Lap Clay hydrogel nanocomposite & Basic Fuchsin (Basic Violet 14) & $\begin{array}{l}\text { Increases of AAm and Lap content in PAAm/ } \\
\text { Lap nanocomposite hydrogel, the } \mathrm{pH} \text { and } \\
\text { temperature of the dye solution increased the } \\
\text { adsorption of basic fuchsin dye. }\end{array}$ & Zhang et al. [92] \\
\hline $\begin{array}{l}\text { Poly(Acrylamide)/א-Carrageenin/Sodium Alginate } \\
\text { Sodium Montmorillonite (MMT) Clay hydrogel } \\
\text { nanocomposite }\end{array}$ & Crystal Violet (CV) & $\begin{array}{l}\text { Dye adsorption capacity of hydrogels } \\
\text { was influenced by both, clay content and } \\
\text { biopolymers weight ratio. At acidic media, the } \\
\text { dye adsorption capacity of nanocomposites was } \\
\text { enhanced as the carrageenan and clay content } \\
\text { were increased. }\end{array}$ & Reza-Mahdavinia et al. [93] \\
\hline Chitosan/Modified Ball (MBC-CH) Clay composite & Methylene Blue (MB) & $\begin{array}{l}\text { Adsorption of } \mathrm{MB} \text { on } \mathrm{MBC}-\mathrm{CH} \text { was found to } \\
\text { increase as the initial concentration, solution } \mathrm{pH} \\
\text { and temperation of the process were increased. }\end{array}$ & Auta and Hameed [94] \\
\hline $\begin{array}{l}\text { Poly(acrylamide-co-acrylic acid)/Kaolinite P(AAm- } \\
\text { AAc/Kao) Clay composite }\end{array}$ & Bromophenol Blue (BPB) & $\begin{array}{l}\text { An increase in temperature resulted in increase } \\
\text { in the amount of BPB dye adsorbed per unit } \\
\text { mass of sorbents }\end{array}$ & El-Zahhar et al. [95] \\
\hline $\begin{array}{l}\text { Poly }(\text { kappa-carrageenin-co-PVA }) / \mathrm{Fe}_{3} \mathrm{O}_{4} \text { magnetic } \\
\text { nanocomposite hydrogels }\end{array}$ & Crystal Violet (CV) & $\begin{array}{l}\text { Removal of CV decreased by the incorporation } \\
\text { of magnetite particles, and was improved by } \\
\text { increasing the ratio of kappa-carrageenan. CV } \\
\text { adsorption capacity of hydrogels decreased with } \\
\text { increasing the ion strength of CV solution. }\end{array}$ & Reza et al. [96] \\
\hline $\begin{array}{l}\text { Poly(N-isopropylacrylamide)/ lithium magnesium } \\
\text { silicate hydrate (LMSH) hydrogel nanocomposite } \\
\text { P(NIPAAm/LMSH) }\end{array}$ & Crystal Violet (CV) & $\begin{array}{l}\text { The adsorption capacity of hydrogel increase } \\
2-4 \text { times when CV concentration was added } \\
\text { from } 10 \text { to } 30 \mathrm{mg} / \mathrm{L} \text {, and increase } 1-1.5 \text { times as } \\
\text { pH value increases from } 3.0 \text { to } 8.9 \text {. }\end{array}$ & Zhang et al. [97] \\
\hline $\begin{array}{l}\text { Polystyrene(PS)/LDH Mg-Al and PS/MMT Clay } \\
\text { nanocomposites }\end{array}$ & $\begin{array}{l}\text { Methyl Orange (MO) and } \\
\text { Methylene Blue (MB) }\end{array}$ & $\begin{array}{l}\text { Clays can be employed to adsorb the organic } \\
\text { dyes (MO and MB), and improve the thermal } \\
\text { stability and smoke suppression properties of } \\
\text { polymer nanocomposites. }\end{array}$ & Zhou et al. [98] \\
\hline $\begin{array}{l}\text { Poly(ethylene glycol-co-acrylic acid)/Bentonite Clay } \\
\text { nanocomposite semi-IPN type hydrogel }\end{array}$ & $\begin{array}{l}\text { Congo Red (CR) and Methyl Violet } \\
\text { (MV) }\end{array}$ & $\begin{array}{l}\text { The nanocomposites showed high adsorption } \\
\text { capacity and removal-\% of CR and MV for low } \\
\text { and high concentrations of them at a solution } \\
\mathrm{pH} \text { of } 7\end{array}$ & $\begin{array}{l}\text { Bhattacharyya and Kumar } \\
\text { [99] }\end{array}$ \\
\hline $\begin{array}{l}\text { Amino-functionalized attapulgite clay nanoparticle } \\
\text { adsorbent (ATP@CCS) onto hydrothermal } \\
\text { carbonized chitosan }\end{array}$ & Methylene Blue (MB) & $\begin{array}{l}\text { The MB adsorption could achieve a quickly } \\
\text { equilibrium (<120 min) with maximum adsorption } \\
\text { capacity of } 215.73 \mathrm{mg} \mathrm{g}^{-1} \text { and the removal of } \\
\text { MB kept above } 80 \% \text { for five consecutive cycles }\end{array}$ & Zhou et al. $[53,54]$ \\
\hline
\end{tabular}

Table 1: Dye removal with polymer-clay composites or nanocomposites.

$25.5 \mathrm{mg} \cdot \mathrm{g}^{-1}$ at room temperature. In Table 2, other results on phenolic compound adsorption with different nanocomposites are shown.

\section{Emerging pollutants}

Emerging pollutants (pharmaceutical products, pesticides, herbicides and personal hygiene products) are compounds of which relatively little is known; as far as their presence, impact and treatment, they are mostly non-regulated pollutants [85].

Antibiotic and antimicrobial agents are between the most widely investigated pharmaceuticals due to their direct effect on the natural microbiota and the formation of resistant strains [86,87], particularly alkylphenol ethoxylates, natural and synthetic hormones and diphenyls, have been addressed.

Putra et al. [88] investigated the removal of amoxicillin from aqueous solutions by adsorption on bentonite. A high value of initial amoxicillin concentration (300 $\left.\mathrm{mg} \cdot \mathrm{L}^{-1}\right)$ was chosen to represent pharmaceutical wastewater. Adsorption of amoxicillin was strongly affected by $\mathrm{pH}$ because it can alter the charge of amoxicillin molecule.
In this study, adsorption capacity of bentonite was compared with a commercial granulated activated carbon (GAC). Both adsorbents were found to be quite effective because removal percentage as high as $88 \%$ was accomplished. $\mathrm{q}_{\mathrm{e}}$ value was comparable (around $20 \mathrm{mg} \cdot \mathrm{g}$ ${ }^{1}$ for bentonite and $25 \mathrm{mg} \cdot \mathrm{g}^{-1}$ for commercial activated carbon), but adsorption equilibrium time for activated carbon was only $35 \mathrm{~min}$ compared to $8 \mathrm{~h}$ of bentonite. The main reason could be the different surface area of the two adsorbents: $92 \mathrm{~m}^{2} \cdot \mathrm{g}^{-1}$ for bentonite and 1,093 $\mathrm{m}^{2} \cdot \mathrm{g}^{-1}$ for GAC.

Bekçi et al. [89] studied montmorillonite as adsorbent in the removal of trimethoprim, one of the main antibacterial agents used in human and veterinary medicine worldwide. As a consequence of thermodynamic studies, the authors verified that physisorption was the chief mechanism of adsorption. Another parameter that affected adsorption of trimethoprim was $\mathrm{pH}$. At low $\mathrm{pH}$ conditions (in an aqueous solution montmorillonite has a $\mathrm{pH}$ value of 3.31), trimethoprim is in the protonated form, so it was adsorbed to the negatively charged surface of the montmorillonite. In the best conditions, the amount of 
Citation: Hernández-Hernández KA, Illescas J, Díaz-Nava MdC, Muro-Urista CR, Martínez-Gallegos S, et al. (2016) Polymer-Clay Nanocomposites and Composites: Structures, Characteristics, and their Applications in the Removal of Organic Compounds of Environmental Interest. Med chem (Los Angeles) 6: 201-210. doi:10.4172/2161-0444.1000347

\begin{tabular}{|c|c|c|c|}
\hline PCN or PCC system & Phenolic Compound & Enhancement action of PCN or PCC system & Authors \\
\hline $\begin{array}{l}\text { Triblock copolymers composites based on } \\
\text { ethylene oxide (EO) and propylene oxide (PO) } \\
\text { units with Laponite (Lap) clay }\end{array}$ & Phenol (PhOH) & $\begin{array}{l}\text { The copolymer replaces } \mathrm{PhOH} \text { from the water/ } \\
\text { Laponite clay interface; moreover, the lateral } \\
\text { copolymer-phenol interactions enhance the } \\
\text { anchoring of } \mathrm{PhOH} \text { to the solid surface and they } \\
\text { are more effective for a composite structure PO- } \\
\text { EO-PO than for a EO-PO-EO. }\end{array}$ & De Lisi et al. [100] \\
\hline $\begin{array}{l}\text { Na-montmorillonite/alginate composites } \\
\text { microcapsules }\end{array}$ & 4-nitrophenol (4NP) & $\begin{array}{l}\text { The } 4 \mathrm{NP} \text { adsorption increases with the proportion } \\
\text { of montmorillonite } \\
\text { in the composite materials, and its adsorption } \\
\text { capacity is strongly affected by the encapsulation. }\end{array}$ & Ely et al. [101] \\
\hline $\begin{array}{l}\text { Nanocomposites of Poly(4-vinylpyridine-co- } \\
\text { styrene) and polydiallyl dimethylammonium } \\
\text { chloride (PDADMAC) with MMT and Sepiolite } \\
\text { (Sep) Clays }\end{array}$ & $\begin{array}{l}\text { Trichlorophenol (TCP) and } \\
\text { Trinitrophenol (TNP) }\end{array}$ & $\begin{array}{l}\text { The adsorption of PDADMAC and PVPcoS to } \\
\text { MMT was faster for both polymers than their } \\
\text { adsorption to the porous SEP. Also, both pollutants } \\
\text { showed higher affinity towards PVPcoS-MMT } \\
\text { nanocomposite. }\end{array}$ & Ganigar et al. [102] \\
\hline $\begin{array}{l}\text { Chitosan- coated-Perlite (CCP) beads } \\
\text { composites }\end{array}$ & $\begin{array}{l}\text { Phenol, 2-chlorophenol and } \\
\text { 4-chlorophenol }\end{array}$ & $\begin{array}{l}\text { CCP beads show higher adsorption capacity for } \\
\text { chlorophenols than phenol. Moreover, the highest } \\
\text { adsorption of phenolic compounds occurred at } \mathrm{pH} \\
7.0 \text { for all species }\end{array}$ & Kumar et al. [47] \\
\hline $\begin{array}{l}\text { Sodium Alginate-Aluminum pillared clay (Al- } \\
\text { MMT- } \\
\text { PILC) or surfactant-modified pillared clay } \\
(\mathrm{CTAB}-\mathrm{Al}-\text { Mont-PILC) and divalent cation } \\
\left(\mathrm{Ca}^{2+}\right) \text {, gel-like beads }\end{array}$ & Pentachlorophenol (PCP) & $\begin{array}{l}\text { Modification of the biopolymers by introduction of } \\
\text { pillared clays resulted in an enhancement of the } \\
\text { adsorption capacity. }\end{array}$ & Lezehari et al. [103] \\
\hline $\begin{array}{l}\text { Poly(acrylamide)/Bentonite-modified with } \\
\text { cethyltrimethyl ammonium (CTMA) composite }\end{array}$ & Phenol (PhOH) & $\begin{array}{l}\text { The sorption capacity of the organobentonites } \\
\text { towards phenol demonstrated to increase until } \\
\text { the maximum, and then began to decrease as the } \\
\text { saturated cationic exchange capacity (CEC) further } \\
\text { increased. }\end{array}$ & [73] \\
\hline $\begin{array}{l}\text { Composite beads of Mauritanian clays (R3, } \\
\text { NKCO } 4, \text { ZS26, ZS23) encapsulated with } \\
\text { sodium alginate (SA) }\end{array}$ & 4-nitrophenol (4NP) & $\begin{array}{l}\text { Adsorption of } 4 \mathrm{NP} \text { was favorized onto activated } \\
\text { carbon and the order was Activated Carbon } \\
\text { (AC)>AC/SA }>\text { Sodium montmorillonite (Na- } \\
\text { MMT)>Na-ZS26/SA, Na-mont/SA. }\end{array}$ & Ely et al. [104] \\
\hline $\begin{array}{l}\text { Poly(glycidyl methacrylate-co-ethylene } \\
\text { glycol dimethacrylate) functionalized with } \\
\text { diethylenetriamine (DETA) and acid modified } \\
\text { bentonite composite }\end{array}$ & 4-nitrophenol (4NP) & $\begin{array}{l}\text { The incorporation of the acid modified clay into the } \\
\text { copolymer matrix lead to the increase of porosity, } \\
\text { total pore volume, specific surface area, and } \\
\text { sorption efficiency of the } 4 \mathrm{NP}\end{array}$ & Marinović et al. [105] \\
\hline $\begin{array}{l}\text { Composite beads of aluminum-pillared clay (Al- } \\
\text { Mont-PILC) and surfactant-modified } \\
\text { pillared clay (CTAB-AI-Mont-PILC) onto } \\
\text { Alginate }\end{array}$ & Pentachlorophenol (PCP) & $\begin{array}{l}\text { Higher values of removal were obtained for the } \\
\text { encapsulated surfactant-modified aluminum- } \\
\text { pillared clay compared with the encapsulated } \\
\text { aluminum-pillared clay. }\end{array}$ & Lezehari et al. [106] \\
\hline $\begin{array}{l}\text { Wheat straw/Palygorskite Clay/Phenolic Resin } \\
\text { Woodceramic composite }\end{array}$ & Phenol (PhOH) & $\begin{array}{l}\text { Palygorskite clay modified woodceramics had the } \\
\text { highest adsorption rate; in addition, the higher the } \\
\text { phenol solution concentration and } \mathrm{pH} \text {, the lower the } \\
\text { adsorption efficiency was. }\end{array}$ & Wu et al. [107] \\
\hline $\begin{array}{l}\text { Poly(glycidyl methacrylate-co-ethylene } \\
\text { glycol dimethacrylate) functionalized with } \\
\text { diethylenetriamine (DETA) and acid modified } \\
\text { bentonite nanocomposite }\end{array}$ & $\begin{array}{l}\text { 2-nitrophenol (2NP), 4-nitrophenol } \\
\text { (4NP) and 2-chloro-4-dinitrophenol } \\
(2 \mathrm{Cl} 4 \mathrm{NP})\end{array}$ & $\begin{array}{l}\text { Affinity of nanocomposite toward phenol derivatives } \\
\text { increases in the following order } 2 \mathrm{NP}<4 \mathrm{NP} \\
<2 \mathrm{Cl} 4 \mathrm{NP} \text {, probably attributed to the hydrogen } \\
\text { bonds that they could form with the sorbent. }\end{array}$ & Marinović et al. [108] \\
\hline
\end{tabular}

Table 2: Phenol and its derivatives removal with polymer-clay nanocomposites or composites.

drug adsorbed was $60 \mathrm{mg} \cdot \mathrm{g}^{-1}$ for $1 \mathrm{~h}$ of contact time (initial compound concentration was $\left.290.3 \mathrm{mg} \cdot \mathrm{L}^{-1}\right)$.

Some other investigations related to the use of nanocomposites for the removal of emerging pollutants are reported and discussed on Table 3.

\section{Conclusions and Perspectives}

As it has been stated in this review, PCN's have significant advantages of established adsorbents for water treatment, for example their easy production, their good performance, and their enhanced. Furthermore, with the data reported here, it is important to mention that polymer nanocomposites are not only studied with the objective of reinforcing the polymer matrix, but also to find improvements in their properties. The advantages of nanoscale clay bonding lead to a number of applications, for instance in barrier properties, in separation membranes, in flame resistance and as polymer compatibilizer, to mention a few.

In the case of polymer matrices of organic origin, the most widely used is chitosan, due to the high removal values found and reported in the tables, while among those of synthetic origin are acrylates, mainly due to the properties they present when external conditions such as $\mathrm{pH}$, temperature, vary. Despite this, PCN's have not reached their total development and currently, from laboratory research to large-scale engineering projects, it is necessary to encourage it, to have an idea of these versatile materials' complete potential and their applications in environmental remediation, specifically for the removal of organic compounds from water.

\section{Acknowledgements}

Authors are thankful to CONACyT, through project Cátedras CONACYT 3056 , 
Citation: Hernández-Hernández KA, Illescas J, Díaz-Nava MdC, Muro-Urista CR, Martínez-Gallegos S, et al. (2016) Polymer-Clay Nanocomposites and Composites: Structures, Characteristics, and their Applications in the Removal of Organic Compounds of Environmental Interest. Med chem (Los Angeles) 6: 201-210. doi:10.4172/2161-0444.1000347

\begin{tabular}{|c|c|c|c|}
\hline PNC or PCC system & Emerging Compound & Enhancement action of PCN or PCC system & Authors \\
\hline Chitosan/MMT composite & Tannic Acid & $\begin{array}{l}\text { The polycation chitosan and montmorillonite is } \\
\text { an adsorbent of relatively high stability and at low } \\
\text { concentrations where tannic acid is completely } \\
\text { dissociated, its adsorption arises electrostatically and } \\
\text { is unaffected by pH. }\end{array}$ & An and Dultz [109] \\
\hline $\begin{array}{l}\text { Nanocomposites of Poly(4-vinylpyridine-co- } \\
\text { styrene) and polydiallyl dimethylammonium } \\
\text { chloride (PDADMAC) with MMT Clay }\end{array}$ & Atrazine (pesticide) & $\begin{array}{l}\text { The polymer-clay composite filter, consisting of } \\
\text { poly(4-vinylpyridine-co-styrene) succeeded in } \\
\text { reducing atrazine concentrations below the current } \\
\text { EPA standard. }\end{array}$ & Zadaka et al. [110] \\
\hline $\begin{array}{l}\text { Montmorillonite (SWy-2)-chitosan } \\
\text { bionanocomposites (SW-CH) }\end{array}$ & $\begin{array}{l}\text { 3,6-dichloropyridine-2-carboxylic acid } \\
\text { (Clopyralid) }\end{array}$ & $\begin{array}{l}\text { The removal of clopyralid from aqueous solution was } \\
\text { greater for bionanocomposites with higher chitosan } \\
\text { contents }\end{array}$ & Celis et al. [111] \\
\hline $\begin{array}{l}\text { Composite of Magnetite/Bentonite Clay } \\
\text { composite }\end{array}$ & Amoxicilin & $\begin{array}{l}\text { The adsorbent mixture was efficient, chemically } \\
\text { inert, and had a removal rate of } 50 \% \text { of amoxicillin } \\
\text { in water. The adsorption process was physical and } \\
\text { activated depending on the temperature. }\end{array}$ & [112] \\
\hline $\begin{array}{l}\text { Poly(4-vinylpyridine-co-styrene)/MMT clay } \\
\text { composite }\end{array}$ & $\begin{array}{c}\text { Triazine, simazine and terbuthylazine } \\
\text { pesticides }\end{array}$ & $\begin{array}{l}\text { Herbicide binding affinity increased with a decrease } \\
\text { in herbicide molecular size due to enhanced } \\
\text { accessibility of the small herbicide to the binding } \\
\text { sites of the polymer. }\end{array}$ & Gardi et al. [113] \\
\hline
\end{tabular}

Table 3: Examples of emerging compounds removed through polymer-clay nanocomposites or composites.

and project TecNM 5646.15P, for the support to this work. Also, Karina Abigail Hernández-Hernández is grateful to CONACyT for her scholarship.

\section{References}

1. Klefenz $\mathrm{H}$ (2004) Nanobiotechnology: from molecules to systems. Engineering in Life Sciences 4: 211-218.

2. Masciangioli T, Zhang $W X$ (2003) Environmental technologies at the nanoscale. Environ Sci Technol 37: 102A-108A

3. Zhang L, Fang M (2010) Nanomaterials in pollution traces detection and environmental improvement. Nanotoday 5: 128-142.

4. Trindade MJ, Dias MI, Coroado J, Rocha F (2009) Mineralogical transformations of calcareous rich clays with firing: A comparative study between calcite and dolomite rich clays from Algarve, Portugal. Applied Clay Science 42: 345-355.

5. Minkova L, Filippi S (2011) Characterization of HDPE-g-MA/clay nanocomposites prepared by different preparation procedures: Effect of the filler dimensión on crystallization, microhardness and flammability. Polymer Testing 30: 1-7.

6. Maneshi A, Soares JBP, Simon LC (2011) Polyethylene/clay nanocomposites made with metallocenes supported on different organoclays. Macromolecular Chemistry and Physics 212: 216-228.

7. Alian AM, Abu-Zahra MH (2009) Mechanical properties of rigid foam PVC-clay nanocomposites. Polymer-Plastics Technology and Engineering 48: 10141019.

8. Timmaraju MV, Gnanamoorthy R, Kannan K (2011) Effect of environment on flexural fatigue behavior of polyamide 66/hectorite nanocomposites. International Journal of Fatigue 33: 541-548.

9. Timmaraju MV, Gnanamoorthy R, Kannan K (2011) Influence of imbibed moisture and organoclay on tensile and indentation behavior of polyamide $66 /$ hectorite nanocomposites. Composites Part B: Engineering 42: 466-472.

10. Anadão P, Sato LF, Wiebeck H, Díaz FRV (2010) Montmorillonite as a component of polysulfone nanocomposite membranes. Applied Clay Science 48: 127-132.

11. Narayanan BN, Koodathil R, Gangadharan T, Yaakob Z, Saidu FK, et al. (2010) Preparation and characterization of exfoliated polyaniline/montmorillonite nanocomposites. Materials Science and Engineering B 168: 242-244.

12. Abraham TN, Siengchin S, Ratna D, Karger-Kocsis J (2010) Effect of modified layered silicates on the confined crystalline morphology and thermomechanical properties of poly(ethylene oxide) nanocomposites. Journal of Applied Polymer Science 118: 1297-1305.

13. Botana A, Mollo M, Eisenberg P, Zanchez RMT (2010) Effect of modified montmorillonite on biodegradable PHB nanocomposites. Applied Clay Science 47: $263-270$
14. Alexandre M, Dubois P (2000) Polymer-layered silicate nanocomposites: preparation, properties and uses of a new class of materials. Materials Science \& Engineering $\mathrm{R}$ 28: 1-63.

15. Esteves ACC, Barros Timmons A, Trindade T (2004) Nanocompositos de matriz polimérica: estrategias de síntesis de materiales híbridos. Química Nova 27: 798-806.

16. Brigatti MF, Galan E, Theng BKG (2006) Structures and mineralogy of clay minerals. Handbook of Clay Science Elsevier, Amsterdam, pp 19-86.

17. Baniasadi H, Ramazani ASA, Nikkhah SJ (2010) Investigation of in situ prepared polypropylene/clay nanocomposites properties and comparing to melt blending method. Materials \& Design 31: 76-84.

18. Strawhecker KE, Manias E (2000) Structure and properties of poly(viny alcohol)/Na+ montmorillonite composites. Chemistry of Materials 12: 29432949.

19. Billingham J, Breen C, Yarwood J (1997) Adsorption of polyamine, polyacrylic acid and polyethylene glycol on montmorillonite: An in situ study using ATRFTIR. Vibrational Spectroscopy 14: 19-34.

20. Malwitz MM, Lin-Gibson S, Hobbie EK, Butler PD, Schmidt G (2003) Orientation of platelets in multilayered nanocomposite polymer films. Journal of Polymer Science, Part B: Polymer Physics 41: 3237-3248.

21. Vaia RA, Ishii H, Giannelis EP (1993) Synthesis and properties of twodimensional nanostructures by direct intercalation of polymer melts in layered silicates. Chemistry of Materials 5: 1694-1696.

22. Di Y, lannace S, Maio ED, Nicolais I (2003) Nanocomposites by melt intercalation based on polycaprolactone and organoclay. Journal of Polymer Science Part B: Polymer Physics 41: 670-678.

23. Finnigan B, Martin D, Halley P, Truss R, Campbell K (2004) Morphology and properties of thermoplastic polyurethane nanocomposites incorporating hydrophilic layered silicates. Polymer 45: 2249-2260.

24. Srivastava SK, Pramanik M, Acharya H (2006) Ethylene/vinyl acetate copolymer/clay nanocomposites. Journal of Polymer Science Part B: Polymer Physics 44: 471-480.

25. Wan C, Qiao X, Zhang Y, Zhang Y (2003) Effect of different clay treatment on morphology and mechanical properties of PVC-clay nanocomposites. Polymer Testing 22: 453-461.

26. Cabedo L, Giménez E, Lagaron JM, Gavara R, Saur JJ (2004) Development of EVOH-kaolinite nanocomposites. Polymer 45: 5233-5238.

27. Akar ST, Uysal R (2010) Untreated clay with high adsorption capacity for effective removal of C.I. Acid Red 88 from aqueous solutions: Batch and dynamic flow mode studies. Chemical Engineering Journal 162: 591-598.

28. Ozcan A, Omeroğlu C, Erdoğan Y, Ozcan AS (2007) Modification of bentonite 
Citation: Hernández-Hernández KA, Illescas J, Díaz-Nava MdC, Muro-Urista CR, Martínez-Gallegos S, et al. (2016) Polymer-Clay Nanocomposites and Composites: Structures, Characteristics, and their Applications in the Removal of Organic Compounds of Environmental Interest. Med chem (Los Angeles) 6: 201-210. doi:10.4172/2161-0444.1000347

with a cationic surfactant: An adsorption study of textile dye Reactive Blue 19. J Hazard Mater 140: 173-179

29. Ojstrsek A, Fakin D (2011) Colour and TOC reduction using biofilter packed with natural zeolite for the treatment of textile wastewater. Desalination and Water Treatment 33: 147-155.

30. Ojstrsek, A, Fakin, D (2011) Colour and TOC reduction using biofilter packed with natural zeolite for the treatment of textile wastewater. Desalination and Water Treatment, 33, 147-155.

31. Rafatullah M, Sulaiman $O$, Hashim R, Ahmad A (2010) Adsorption of methylene blue on low-cost adsorbents: a review. J Hazard Mater 177: 70-80.

32. Mahamuni NN, Pandit AB (2005) Effect of additives on ultrasonic degradation of phenol. Ultrasonics Sonochemistry 13: 165-174.

33. Maleki A, Malvi AH, Vaezi F, Nabizadeh R (2005) Ultrasonic degradation of phenol and determination of the oxidation byproduct toxicity Iran. Journal of Environmental Health Science and Engineering 2: 201-216.

34. Sarkar M, Acharya PK (2006) Use of fly ash for the removal of phenol and its analogues from contaminated water. Waste Manag 26: 559-570.

35. Olujimi OO, Fatoki OS, Odendaal JP, Okonkwo JO (2010) Endocrine disrupting chemicals (phenol and phthalates) in the South African environment: a need for more monitoring. Water SA 36: 671-682.

36. Mahvi AH (2008) Application of agricultural fibres in pollution removal from aqueous solution: A review. International Journal of Environmental Science \& Technology 5: 275-285

37. Fent K, Weston AA, Caminada D (2006) Ecotoxicology of human pharmaceuticals. Aquat Toxicol 76: 122-159.

38. Elorriaga Y, Marino DJ, Carriquiriborde P, Ronco AE (2012) Contaminantes Emergentes: Productos Farmacéuticos en el Medio Ambiente. $7^{\text {th }}$ Congreso de Medio Ambiente/AUGM.

39. Spongberg AL, Witter JD (2008) Pharmaceutical compounds in the wastewater process stream in Northwest Ohio. Science of the Total Environment 397: 148157

40. Yoon Y, Ryu J, Oh J, Choi BG, Snyder SA (2010) Occurrence of endocrine disrupting compounds, pharmaceuticals, and personal care products in the Han River (Seoul, South Korea). Science of The Total Environment 408: 636-643.

41. Namasivayam C, Kanchana N (1992) Waste banana pith as adsorbent for color removal from wastewaters. Chemosphere 25: 1691-1705.

42. Namasivayam C, Yamuna RT (1992) Removal of Congo Red from aqueous solutions by biogas waste slurry. Journal of Chemical Technology and Biotechnology 53: 153-157.

43. Namasivayam C, Muniasamy N, Gayathri K, Rani M, Ranganathan K (1996) Removal of dyes from aqueous solutions by cellulosic waste orange peel. Bioresource Technology 57: 37-43.

44. Namasivayam C, Arasi DJSE (1997) Removal of Congo Red from wastewater by adsorption onto waste red mud. Chemosphere 34: 401-417.

45. Gil A, Assis FCC, Albeniz S, Korili SA (2011) Removal of dyes from wastewaters by adsorption on pillared clays. Chemical Engineering Journal 168: 1032-1040.

46. Gupta VK, Suhas (2009) Application of low-cost adsorbents for dye removal--a review. J Environ Manage 90: 2313-2342.

47. Kumar NS, Suguna M, Subbaiah MV, Reddy AS, Kumar NP, et al. (2010) Adsorption of Phenolic Compounds from Aqueous Solutions onto ChitosanCoated Perlite Beads as Biosorbent. Industrial \& Engineering Chemistry Research 49: 9238-9247.

48. Kumar VA, Dash RR, Bhunia P (2012) A review on chemical coagulation/ flocculation technologies for removal of color from textile wastewaters. Journal or Environmental Management 93: 154-168.

49. Kyzas G Z, Lazaridis NK, Mitropoulos AC (2012) Removal of dyes from aqueous solutions with untreated coffee residues as potential low-cost adsorbents: Equilibrium, reuse and thermodynamic approach. Chemical Engineering Journal 189-190: 148-159.

50. Escobar-Jiménez J, Muro-Urista C, Esparza-Soto M, Gómez-Espinoza RM, Díaz-Nava MC, et al. (2012) Recuperación de agua de efluentes de una industria de cereales utilizando membranas. Tecnología y Ciencias del Agua 3: 65-82.

51. Zahrim AY, Tizaoui C, Hilal N (2011) Coagulation with polymers for nanofiltration pre-treatment of highly concentrated dyes: A review. Desalination 266: 1-16.

52. Zahrim AY, Hilal N (2013) Treatment of highly concentrated dye solution by coagulation/flocculation-sand filtration and nanofiltration. Water Resources and Industry 3: 23-34.

53. Zhou Q, Gao Q, Luo W, Yan C, Ji, Z, et al. (2015) One-step synthesis of amino-functionalized attapulgite claynanoparticles adsorbent by hydrotherma carbonization of chitosanfor removal of methylene blue from wastewater Colloids and Surfaces A: Physicochemical and Engineering Aspects 470: 248-257.

54. Zhou Y, Dai Z, Zhai D, Gao C (2015) Surface modification of polypiperazineamide membrane by self-assembled method for dye wastewater treatment Chinese Journal of Chemical Engineering 23: 912-918.

55. Khouni I, Marrot B, Moulin P, Ben Amar R (2011) Decolourization of the reconstituted textile effluent by different process treatments: Enzymatic catalysis, coagulation/flocculation and nanofiltration processes. Desalination 268: 27-37.

56. Solís M, Solís A, Pérez HI, Manjarrez N, Flores M (2012) Microbial decolouration of azo dyes: A review. Process Biochemistry 47: 1723-1748.

57. Djellabi R, Ghorab MF, Cerrato G, Morandi, S, Gatto, S, et al. (2014) Photoactive TiO2-montmorillonite composite for degradation of organic dyes in water. Journal of Photochemistry and Photobiology A: Chemistry 295: 57-63.

58. Li H, Li Y, Xiang L, Huang Q, Qiu J, et al. (2015) Heterogeneous photo-Fenton decolorization of Orange II overAl-pillared Fe-smectite: Response surface approach, degradation pathway, and toxicity evaluation. Journal of Hazardous Materials 287: 32-41.

59. Ahmad A, Mohd-Setapar SH, Chuo SC, Khatoon A, Wani WA, et al. (2015) Recent Advances in New Generation Dye Removal Technologies: Nove Search of Approaches to Reprocess Waste Water. RSC Advances 5: 3080130818.

60. Auta M, Hameed BH (2012) Modified mesoporous clay adsorbent for adsorption isotherm and kinetics of methylene blue. Chemical Engineering Journal 198199: 219-227.

61. Chen H, Zhao J, Zhong A, Jin Y (2011) Removal capacity and adsorption mechanism of heat-treated palygorskite clay for methylene blue. Chemical Engineering Journal 174: 143-150.

62. Hashemian S, Reza-Shahedi M (2013) Novel Ag/Kaolin Nanocomposite as Adsorbent for Removal of Acid Cyanine 5R from Aqueous Solution. Journal of Chemistry 2013: 1-7.

63. Hashemian S, Sadeghi B, Mozafari F, Salehifar H, Salari K (2013) Adsorption of Disperse of Yellow 42 onto Bentonite and Organo-Modified Bentonite by Tetra Butyl Ammonium lodide (B-TBAI). Polish Journal of Environmental Studies 22: 1363-1370.

64. Hernández-Hernández KA, Solache-Ríos M, Díaz-Nava MC (2013) Remova of Brilliant Blue FCF from Aqueous Solutions Using an Unmodified and IronModified Bentonite and the Thermodynamic Parameters of the Process. Water, Air and Soil Pollution 224: 1562-1572.

65. Kant R (2012) Adsorption of Dye Eosin from an Aqueous Solution on Two Different Samples of Activated Carbon by Static Batch Method. Journal of Water Resource and Protection 4: 93-98.

66. Kaur M, Datta M (2011) Adsorption Characteristics of Acid Orange 10 from Aqueous Solutions onto Montmorillonite Clay. Adsorption Science \& Technology 29: 301-318.

67. DíazGómez-Treviño AP, Martínez-Miranda V, Solache-Ríos M (2013) Removal of remazol yellow from aqueous solutions by unmodified and stabilized iron modified clay. Applied Clay Science 80-81: 219-225.

68. Yagub MT, Kanti-Sen T, Afroze S, Ang HM (2014) Dye and its removal from aqueous solution by adsorption: A review. Advances in Colloid and Interface Science 209: 172-184.

69. Ahmaruzzaman M (2008) Adsorption of phenolic compounds on low-cost adsorbents: A review. Adv Colloid Interface Sci 143: 48-67.

70. Lin SH, Juang RS (2009) Adsorption of phenol and its derivatives from water using synthetic resins and low-cost natural adsorbents: A review. Journal of Environmental Management 90: 1336-1349.

71. Britto JM, Rangel MD (2008) Advanced oxidation process of phenolic compounds in industrial wasterwater. Quim Nova 31: 114-122.

72. Qayyum H, Maroof H, Yasha K (2009) Remediation and treatment of 
Citation: Hernández-Hernández KA, Illescas J, Díaz-Nava MdC, Muro-Urista CR, Martínez-Gallegos S, et al. (2016) Polymer-Clay Nanocomposites and Composites: Structures, Characteristics, and their Applications in the Removal of Organic Compounds of Environmental Interest. Med chem (Los Angeles) 6: 201-210. doi:10.4172/2161-0444.1000347

organopollutants mediated by peroxidases: a review. Crit Rev Biotechnol 29: 94-119.

73. Liao CJ, Chen CP, Wang MK, Chiang PN, Pai CW (2006) Sorption of chlorophenoxy propionic acids by organoclay complexes. Environ Toxicol 21: 71-79.

74. Floody MC, Theng BKG, Reyes P, Mora ML (2009) Natural nanoclays: applications and future trends-a Chilean perspective. Clay Minerals 44: 161-176.

75. Smith KM, Fowler GD, Pullket S, Graham NJD (2009) Sewage sludge-based adsorbents: a review of their production, properties and use in water treatment applications. Water Research 43: 2569-2594.

76. Faust SD, Aly OM (1998) Chemistry of Water Treatment. CRC, USA, pp: 127483.

77. Zhao H, Vance FG (1998) Sorption of trichloroethylene by organoclays in the presence of humic substances. Water Research 32: 3710-3716.

78. Dabrowski A, Podkoscielny P, Hubicki Z, Barczak M (2005) Adsorption of phenolic compounds by activated carbon--a critical review. Chemosphere 58 : 1049-1070.

79. Gonen Y, Rytwo G (2006) Using the dual-mode model to describe adsorption of organic pollutants onto an organoclay. J Colloid Interface Sci 299: 95-101.

80. Site AD (2001) Factors affecting sorption of organic compounds in natural sorbent water systems and sorption coefficients for selected pollutants: A review. Journal of Physical Chemistry 30: 187-439.

81. Beall GW (2003) The use of organoclays in water treatment. Applied Clay Science 24: 11-20.

82. Moon H, Kook SK, Park HC (1991) Adsorption of phenols onto a polymeric sorbent. Korean Journal of Chemical Engineering 8: 168-176.

83. Soni A, Tiwari A, Bajpal AK (2012) Adsorption of o-nitrophenol onto nano iron oxide and alginate microspheres: Batch and column studies. African Journal of Pure and Applied Chemistry 6: 161-173.

84. Chen S, Xu ZP, Zhang Q, Maxhu GQ, Hao ZP, et al. (2009) Studies on adsorption of phenol and 4-nitrophenol on MgAl-mixed oxide derived from MgAl-layered double hydroxide. Separation and Purification Technology 67: 194-200.

85. Gil MJ, Soto AM, Usma JI, Gutiérrez OD (2012) Contaminantes emergentes en aguas, efectos y posibles tratamientos. Producción + Limpia, 7: 52-73.

86. Gao J, Pedersen JA (2005) Adsorption of sulfonamide antimicrobial agents to clay minerals. Environ Sci Technol 39: 9509-9516.

87. Kasprzyk-Hordern B, Dinsdale RM, Guwy AJ (2007) Multi-residue method for the determination of basic/neutral pharmaceuticals and illicit drugs in surface water by solid-phase extraction and ultra-performance liquid chromatographypositive electrospray ionisation tandem mass spectrometry. Journal of Chromatography A 1161: 132-145.

88. Putra EK, Pranowo R, Sunarso J, Indraswati N, Ismadji S (2009) Performance of activated carbon and bentonite for adsorption of amoxicillin from wastewater: mechanisms, isotherms and kinetics. Water Res 43: 2419-2430.

89. Bekçi Z, Seki Y, Yurdakoç MK (2006) Equilibrium studies for trimethoprim adsorption on montmorillonite KSF. Journal of Hazardous Materials B133: 233-242.

90. Shirsath SR, Hage AP, Zhou M, Sonawane SH, Ashokkumar M (2011) Ultrasound assisted preparation of nanoclay Bentonite-FeCo nanocomposite hybrid hydrogel: A potential responsive sorbent for removal of organic pollutant from water. Desalination 281: 429-437.

91. Reza-Mahdavinia G, Massoumi B, Jalili K, Kiani G (2012) Effect of sodium montmorillonite nanoclay on the water absorbency and cationic dye removal of carrageenan-based nanocomposite superabsorbents. Journal of Polymer Research 19: 9947-9960.

92. Zhang X, Zheng S, Lin Z, Zhang J (2012) Removal of Basic Fuchsin Dye by Adsorption onto Polyacrylamide/Laponite Nanocomposite Hydrogels. Synthesis and Reactivity in Inorganic, Metal-Organic, and Nano-Metal Chemistry 42: 1273-1277.

93. Reza-Mahdavinia G, Aghaie H, Sheykhloie H, Vardini MT, Etemadi H (2013) Synthesis of CarAlg/MMt nanocomposite hydrogels and adsorption of cationic crystal violet. Carbohydrate Polymers 98: 358-365.

94. Auta M, Hameed BH (2014) Chitosan-clay composite as highly effective and low-cost adsorbent for batch and fixed-bed adsorption of methylene blue Chemical Engineering Journal 237: 352-361.

95. El-Zahhar AA, Awwad NS, El-Katori EE (2014) Removal of bromopheno blue dye from industrial waste water by synthesizing polymer-clay composite. Journal of Molecular Liquids 199: 454-461.

96. Reza-Mahdavinia G, Massoudi A, Baghban A, Shokri E (2014) Study of adsorption of cationic dye on magnetic kappa-carrageenan/PVA nanocomposite hydrogels. Journal of Environmental Chemical Engineering 2: 1578-1587.

97. Zhang Q, Zhang T, He T, Chen L (2014) Removal of crystal violet by clay/ PNIPAmnanocomposite hydrogels with various clay contents. Applied Clay Science 90: 1-5.

98. Zhou K, Zhang Q, Wang B, Liu J, Wen P, et al. (2014) The integrated utilization of typical clays in removal of organic dyes and polymer nanocomposites. Journal of Cleaner Production 81: 281-289.

99. Bhattacharyya R, Kumar-Ray S (2015) Removal of congo red and methyl viole from water using nano clay filled composite hydrogels of poly acrylic acid and polyethylene glycol. Chemical Engineering Journal 260: 269-283.

100.De Lisi R, Lazzara G, Milioto S, Muratore N (2006) Aqueous Nonionic Copolymer-Functionalized Laponite Clay. A Thermodynamic and Spectrophotometric Study to Characterize Its Behavior toward an Organic Material. Langmuir 22: 8056-8062.

101.Ely A, Baudu M, Basly JP, Kankou MO (2009) Copper and nitrophenol pollutants removal by Na-montmorillonite/alginate microcapsules. J Hazard Mater 171: 405-409.

102. Ganigar R, Rytwo G, Gonen Y, Radian A, Mishael YG (2010) Polymer-clay nanocomposites for the removal of trichlorophenol and trinitrophenol from water. Applied Clay Science 49: 311-316.

103.Lezehari M, Basly JP, Baudu M, Bouras O (2010) Alginate encapsulated pillared clays: removal of a neutral/anionic biocide (pentachlorophenol) and a cationic dye (safranine) from aqueous solutions. Colloids and Surfaces A: Physicochemical and Engineering Aspects 366: 88-94.

104. Ely A, Baudu M, Kankou MOSAO, Basly JP (2011) Copper and nitropheno removal by low cost alginate/Mauritanian clay composite beads. Chemical Engineering Journal 178: 168-174.

105. Marinovic SR, Milutinovic-Nikolic AD, Žunic MJ, Vukovic ZM, Maksin D, et al. (2011) Porous glycidyl methacrylate-bentonite composite. Russian Journal of Physical Chemistry A 85: 2386-2391.

106. Lezehari M, Baudu M, Bouras O, Basly JP (2012) Fixed-bed column studies of pentachlorophenol removal by use of alginate-encapsulated pillared clay microbeads. J Colloid Interface Sci 379: 101-106.

107. Wu WT, Nie ZF, Tan FI, Xu F, Xu L, et al. (2013) The Preparation of Palygorskite Clay Modified Woodceramics from Wheat Straw and the Absorption of them to the Phenol Wastewater. Polymers \& Polymer Composites 21: 565-572.

108. Marinovic SR, Milutinovic-Nikolic AD, Nastasovic AB, Žunic MJ, Vukovic $Z M$, et al. (2014) Sorption of different phenol derivatives on a functionalized macroporous nanocomposite of poly(glycidyl methacrylate-co-ethylene glycol dimethacrylate) and acid modified bentonite. Journal of the Serbian Chemical Society 79: 1249-1261.

109. An JH, Dultz S (2007) Adsorption of tannic acid on chitosan-montmorillonite as a function of $\mathrm{pH}$ and surface charge properties. Applied Clay Science 36: 256-264.

110. Zadaka D, Nir S, Radian A, Mishael AG (2009) Atrazine removal from water by polycation-clay composites: Effect of dissolved organic matter and comparison to activated carbon. Water Research 43: 677-683.

111. Celis R, Adelino MA, Hermosin MC, Cornejo J (2012) Montmorillonitechitosan bionanocomposites as adsorbents of the herbicide clopyralid in aqueous solution and soil/water suspensions. Journal of Hazardous Materials 209-210: 67-76.

112. Pavlidou S, Papaspyrides CD (2008) A review on polymer-layered silicate nanocomposite. Progress in Polymer Science 33: 1119-1198.

113. Gardi I, Nir S, Mishael YG (2015) Filtration of triazine herbicides by polymerclay sorbents: Coupling an experimental mechanistic approach with empirical modeling. Water Research 70: 64-73. 